\title{
SOME PROBLEMS OF POLICY AND PROCEDURE IN THE CONDUCT OF REORGANIZATION PROCEEDINGS
}

\author{
Carlos L. Israels $\dagger$ \\ "The Law is the true embodiment \\ Of everything that's excellent, \\ It has no kind of fault or flaw ..." \\ "Things are seldom what they seem, \\ Skim milk masquerades as cream." \\ W. S. Gilbert*
}

The origins of modern reorganization practice do not lie in bankruptcy. An understanding of the major procedural steps and problems involved in the conduct of a typical reorganization proceeding under Chapter X of the Bankruptcy Act, therefore, requires some knowledge of its historical background. At the outset, it must be assumed that a debtor's financial condition is such that reorganization rather than liquidation is indicated. This does not necessarily mean that it is solvent in the bankruptcy sense and insolvent merely in that it cannot meet its debts as they mature in the ordinary course of business. It does mean that the enterprise is one of conceded economic value, worth preserving as a going concern from the standpoint of its creditors, if not its stockholders.

In the typical case, a corporate debtor will, perhaps, be unable to meet a maturing installment of interest or principal on its funded debt. It may be that a "voluntary" plan of reorganization has been tried and failed, the bondholders, perhaps, not having sufficient confidence in the management and future prosperity of the debtor to reduce their claims for interest or to place them upon an income basis, even though some

† A. B., I925, Amherst College; LL. B., I928, Columbia University; member of the New York Bar; author of THE ADMINISTRATION OF JUSTICE IN SOvIET RUSSIA IN THE SECOND DECADE (I928); co-author with Milton A. Kramer of The Significance of the Income Clause in a Corporate Mortgage (1930) 30 Cor. L. REv. 488, contributor to legal periodicals.

* This article is a development of lecture material used by the writer at the Practicing Iaw Institute, New York City, in the courses on Corporate Practice and on Bankruptcy and Reorganization. My distinguished co-contributors to this issue will "embody the law" for the benefit of the readers of this Revrew. The writer's task is different-to undertake to present in brief compass some demonstration of the background which, in his view, makes the second of the foregoing quotations, rather than the first, applicable to reorganization practice and procedure under the Bankruptcy Act, and to attempt an evaluation of some of the benefits and remaining deficiencies of reorganization technique as it is used today, from the standpoint of the practicing lawyer who, in one or another capacity, will share in the active conduct of a proceeding. The quotations are extracted from Iolanthe, Act I, and H. M. S. Pinafore, Act Il. 
compensation therefor may be offered in the form of equity participation. Time, and a respite from creditors' pressure are required. Only a court with broad injunctive powers can provide these and, during the interval, give parties in interest time to negotiate, and the court adequate opportunity to consider the fairness, equity and feasibility of any proposed readjustment.

There are four major stages of the reorganization process, each meriting separate consideration. They are:

I. The obtaining of jurisdiction over the debtor's property.

2. The problem of personnel and technique of administration of that property under court supervision.

3. The problem of formulation and court approval of a plan.

4. The consummation of that plan (including its approval by creditors and stockholders). ${ }^{1}$

\section{The Background}

At each of these stages, problems of policy and administration of greater or less importance have arisen. Among these were the problems of jurisdiction beyond the territorial limits of the reorganization court and the necessity for payment of dissenting creditors in cash. Attempts have been made to deal with them through judicial precedent and by statute.

The reorganization acts ${ }^{2}$ are the result of a half century of experience. They are a synthesis of the views of several groups-a group

I. These categories are, of course, arbitrary. The placing of security-holder approval at the fourth stage is dictated by the apparent theory of Chapter $\mathrm{X}$ of the Bankruptcy Act of 1938. Under earlier practice, "consummation" was a more or less mechanical process.

2. Sections 77 and 77B of the Bankruptcy Act of 1898 (added in 1933 and 1934 respectively) and Chapter X of the Bankruptcy Act of 1938 (the Chandler Act) will be loosely referred to herein as "the reorganization acts". Section 77, 47 STAT. I474 (1933), was substantially amended in 1935, 49 STAT. 9II, II U. S. C. A. § 205 (I935). It deals exclusively with the reorganiation of interstate railroads. Though some understanding of railroad reorganization is necessary to a discussion of industrial and real estate reorganizations, Section 77 will not be considered in detail here, since its provisions, particularly since 1935, are peculiar to railroads. In its present'version, it has been much criticized, primarily for the inevitable delays which procedure under it involves, particularly the necessity for two full-dress hearings on the fairness of any plan-one before the Interstate Commerce Commission and the other before the court prior to the submission of that plan to security holders. No Class I railroad has yet been discharged from reorganization under its provisions, despite the fact that it has been on the statute books for seven years, and that some of the proceedings now pending under it were instituted in its earliest days; e. g., Wabash, Rock Island, Frisco, Missouri-Pacific and Milwaukee.

- Section 77B, 48 STAT. 9I2, II U. S. C. A. \$207 (1934) was superseded by Chapter $\mathrm{X}$ in 1938, 52 STAT. 883, II U. S. C. A. $\$ \$ 501-676$ (1938). These sections amend Section $77 \mathrm{~B}$ along with other sections of the Bankruptcy Act of 1898 , and are applicable to any proceeding instituted within three months prior to its effective date, June 22, 1938, and "to the extent that the judge shall deem practicable", are to be applied to proceedings previously instituted under Section $77 \mathrm{~B}$.

For a time, it seemed that Chapter XI of the I938 Act, 52 STAT. 905, II U. S. C. A. $\$ \S 701-799$ (1938), might also be considered, to some extent, to supersede Section 
of active practitioners in the reorganization field, ${ }^{3}$ a group of active bankruptcy practitioners, and the Securities and Exchange Commission. ${ }^{4}$ The result is, naturally, something of a hybrid. If it be borne in mind, however, where the origins lie and that the reorganization acts are bankruptcy statutes primarily for constitutional reasons, the picture clears. By resort to the bankruptcy power of Congress, an easy way was found to give a federal court jurisdiction over all of a debtor's property located in more than one state or federal district. There, also, lay the clear power to do away with cash payments to dissenting creditors. Broadly speaking, the reorganization acts are bankruptcy statutes in name only. At least, as Sections 77 and $77 \mathrm{~B}$ were originally enacted, ordinary bankruptcy practice and procedure were written into them as sparingly as seemed required and bankruptcy courts in reorganization proceedings were specifically granted all the powers of a federal court sitting in equity. In Chapter $\mathrm{X}$, as will appear, the influence of the bankruptcy group among the draftsmen was more powerful, ${ }^{5}$ but still no disturbance to the fundamental pattern resulted.

Reorganization procedure was first worked out in the railroad cases where the fact that railroads could not become bankrupts, combined with the public interest in their continued operation, made unsuitable the normal processes for enforcement of creditors' claims by piecemeal exec'stion sales of the defendant's property. State court procedures were found inadequate or restricted in scope by reason of the territorial limits of the jurisdiction of state courts and, in many instances, the lack of general equity powers in those courts. Therefore, the federal equity receivership, originally designed as a remedy in aid of execution after judgment, looking toward the marshalling and liquidation by sale of the defendant's assets, was adapted to the opposite purpose-the preservation of those assets as a going concern pending readjustment of the rights of creditors and stockholders.

$77 \mathrm{~B}$; that where a corporation had only an unsecured debt, no matter what its amount or public distribution, resort might be had to a simple procedure, akin to a composition under Section I2 of the Bankruptcy Act of 1898. Such was not the intention of the draftsmen of Chapter XI, and their views have been upheld by the Supreme Court. Securities \& Exchange Commission v. United States Realty \& Improvement Co., 60 Sup. Ct. 1044 (I940).

For a succinct history of reorganization procedure, see Findetrer, PrInCtPles of CoRporate REORganization IN BANKRUPTCY (2d ed. I939) I-34; for a discussion of the nature, antecedents and constitutionality of Section 77B, see I GERDES, CoRPORATE Reorganizations (1936) chapters I and 2; for the particular origins of Chapter $\mathrm{X}$, see Heuston, Corporate Reorganization under the Chandler Act (1938) 38 Coz. L. REv. II99.

New York.

3. Typified by a special committee of the Association of the Bar of the City of

4. Heuston, note 2 supra at 1204 .

5. Ibid. 
Once it became evident that a railroad could not meet its debts as they matured in the ordinary course of business, reorganization was indicated. To bring the property within the jurisdiction of the federal court was no easy task. Indenture trustees, to which a maturing installment of interest which might be the cause of the anticipated default was owed, could not yet move. By the time that installment had matured and the period of grace allowed under the mortgage had expired, individual bondholders might have sued on coupons and general creditors might have obtained state court judgments and levied executions thereunder. In any event, suit by the indenture trustee would be in foreclosure. Receivership as an aid to foreclosure had long been recognized, but its incidence would be upon the mortgaged assets only. Thus, it would fail of its purpose to bring the entire operating entity within the jurisdiction of the court. ${ }^{6}$

In addition, it was deemed desirable that the conduct of the proceedings be in friendly hands. A "foreign" general creditor was, therefore, found who was owed more than the jurisdictional amount. That creditor filed a bill of complaint in the selected forum ${ }^{7}$ alleging that the road was insolvent in that it could not meet its debts in the ordinary course of business, but that its assets were of substantially greater value than its liabilities and required preservation pending their marshalling and sale in satisfaction of the defendant's debts.

The bill had a jurisdictional defect. It failed to allege the existence of a judgment in favor of the complainant and the return of execution unsatisfied. That defect was "cured" or "waived" by the filing of an answer in which the defendant admitted the allegations of the bill and joined in the prayer for the appointment of a receiver. In effect, therefore, the receivership was a voluntary one. Once the receiver was appointed in the primary jurisdiction, there would occur a race for ancillary jurisdiction. Ancillary bills of complaint, answers and orders appointing receivers had to be submitted at least in every judicial circuit where the road had property and, if that property were not physically interconnected, in each federal district. ${ }^{8}$

The rule of comity usually dictated the appointment of the same receivers, but counsel did not breathe easily until this was accomplished. Thereafter, as bond issues went into default, indenture trustees applied to the receivership court for leave to foreclose their mort-

6. Israels and Kramer, The Significance of the Income Clause in a Corporate Mortgage (1930) 30 CoL. L. REv. 489, and cases cited. Cf. Kneeland v. American Loan \& Trust Co., 136 U. S. 89 (1890).

7. Usually the jurisdiction in which the principal offices of the road were located, not always the state of incorporation.

8. Lion Bonding \& Surety Co. v. Karatz, 262 U. S. 77 (I923) interpreting Sections 55 and 56 of the Judicial Code, 36 STAT. II02 (I9II), 28 U. S. C. A. \$\$ II6-II7 (1927). 
gages either by intervention or by separate suit which would be promptly consolidated with the receivership, and sought and obtained the "extension" of the receivership to the foreclosure bills. The ground of jurisdiction of these foreclosure suits was simply that the property was already under administration by the federal court. Diversity of citizenship was no longer necessary.

The procedure was quickly adapted to public utility and to industrial and real estate corporations, although Mr. Justice Brandeis warned, as late as I934, that:

"All the cases in which this court appears to have exercised this power in aid of reorganization upon the ground of insolvency dealt with railroads or other public utilities where continued operation of the property and preservation of its unity seemed to be required in the public interest." 9

During receivership, the litigation aspect of the proceeding might be somnolent for months or years, save for the perfunctory observance of the technicalities of foreclosure or the trial or argument of controversies as to conflicting liens or preferred claims, ${ }^{10}$ until a plan of reorganization had been agreed upon by interests nominally unrepresented before the court-usually securityholders' committees. Then a decree of sale would be presented recognizing for the first time in the proceeding that reorganization might have been in view. That decree provided for a sale at public auction. Bidders were required to "qualify" in advance by making substantial deposits of cash or claims and, if it was proposed to bid pursuant to any plan of reorganization, to file a copy of that plan, the fairness and equity of which, if the bidder were successful, would be passed upon by the court as an incident to confirmation of the sale. The sale, theoretically at "public" auction, was in the vast majority of cases a meaningless and expensive gesture. ${ }^{11}$ Competitive bidding was almost non-existent, but for the protection of dissenting creditors, the property was carefully parcelled according to the liens and upset prices placed upon the individual parcels and upon the entirety, prices not representing the value of the property, but merely the lowest figures at which the court felt it might permit the majority to buy off the dissenters. ${ }^{12}$ The property was purchased pur-

9. First National Bank of Cincinnati v. Flershem, 290 U. S. 504, 515 (I934). (Italics added.)

10. This was a fertile field of controversy. See FitzGibbon, The Present Status of the Six Month' Rule (I934) 34 CoL. L. REv. 230.

II. Cf. Phipps v. Chicago, Rock Island \& Pacific Ry. Co., 284 Fed. 945 (C. C. A. 8 th, Ig22) and the procedure suggested in the District Court, referred to in National Surety Co. v. Coriell, 289 U. S. 426 (1933).

12. II GERDES, op. cit. supra note 2 at 1686 et seq.; Spring, Upset Prices in Corporate Reorganization (1929) 42 HARV. L. REv. 899; Weiner, Conflicting Functions 
suant to the plan by reorganization managers who transferred their bid to a new corporation in consideration of its promise to issue its securities in accordance with the plan upon the order of the committees. Confirmation of sale and incident approval of the plan was the final step.

The technique was fictional in important respects. Attempts at judicial realism, such as Judge Sanborn's decree in the Rock Island case, returning the property to the debtor and enjoining future interference therewith, met with well founded doubts as to their validity. ${ }^{18}$

\section{Obtaining JURISDiction}

At the first stage-obtaining jurisdiction over the debtor's property-the procedure was greatly simplified by the reorganization acts which eliminated the problem of ancillary proceedings and provided for the filing of a voluntary petition frankly stating its purpose-the accomplishment of reorganization. ${ }^{14}$

Involuntary proceedings were also provided for. Under Section $77 \mathrm{~B}$, three creditors having claims aggregating $\$ \mathrm{I}, 000$ or more above the value of their security, if any, could file an involuntary petition. In the ordinary case, however, a petition filed by secured bondholders would merely open the way for a contest as to the value of the mortgaged assets, if not on the issue of insolvency or the existence of an act of bankruptcy. Chapter $\mathrm{X}$ is more realistic. The holders of $\$ 5,000$ in total debt, secured or unsecured, may file an involuntary petition, as may an indenture trustee. Such a petition need not show an act of bankruptcy, provided it be shown that the debtor has been adjudicated a bankrupt in a pending proceeding, or that a receiver or trustee has been appointed for or has taken charge of all or a greater portion of the debtor's property, or that an indenture trustee is, by reason of default, in possession of such property, or that a proceeding to fore-

of the Upset Price in a Corporate Reorganization (I927) 27 CoL. L. REv. I32. Under the reorganization acts, the function of the upset price may be somewhat different. A more definite relation to value on some basis is indicated. See FINLETTER, op. cit. supra note 2 at $446,526-530$.

I3. Phipps v. Chicago, Rock Island \& Pacific Ry., 284 Fed. 945 (C. C. A. 8th, 1922). The validity of the procedure in this case was not passed upon by the Supreme Court, and was the subject of serious controversy. See Rosenberg, $A$ New Scheme of Reorganization (I917) 17 CoL. L. REv. 523, Reorganization-The Next Step (1922) 22 CoL. L. REv. I4, Phipps v. Chicago, Rock Island \& Pacific Ry. (1924) 24 CoL. L. Rev. 266'; Swaine, Reorganization-The Next Step: $A$ Reply to Mr. James N. Rosenberg (I922) 22 CoL. L. REv. I2I, Reorganization of Corporations: Certain Developments of the Last Decade (I927) 27 CoL. L. REv. goI; Walker, Reorganization by Decree: Recent Notezorthy Instances (I92I) 6 CoRN. L. Q. 154 . The discussion continued up to the passage by Congress of Section 77 .

14. The contents of the petition are in other respects analogous to the equity bill of complaint. They are indicated in Chapter X, $\$ 126$ et seq. 
close a mortgage or to enforce a lien against all or a greater portion of the property of the debtor is pending. ${ }^{15}$

\section{AdMinistration}

At the second stage, the acts have not been so helpful. Upon the approval of the petition as properly filed, the court must struggle with the most difficult unsolved problem of reorganization practice-the appointment of trustees. A famous equity receivership judge is often quoted as having said that it was his custom to appoint two receivers, one who was familiar with the business and could operate it, and the other in whom he had personal confidence, to watch the first one.

Under Chapter X, this adage is reversed. The judge must appoint an "independent" trustee where the debtor owes more than $\$ 250,000$. The function of that trustee is substantially broader than that of an equity receiver or a trustee in ordinary bankruptcy. $\mathrm{He}$ must assume responsibility not only for operations, but also for a recommendation to the court as to whether or not an investigation should be made of the debtor's affairs, the desirability of continuing its business, the existence of possible causes of action against officers and directors, etc. He must also conduct such investigation, if made, and, at a later stage of the proceedings, formulate a plan. Only as to operations may the independent trustee share his responsibility with a co-trustee who may be a former officer, director or underwriter for the debtor, but who is forbidden by statute from having anything to do with the conduct of the proceeding or the formulation of a plan.

Under equity practice, prior to the enactment of Section $77 \mathrm{~B}$, the most frequent criticism of court appointments of receivers was that the court was too prone to listen to the argument of those in control of the debtor, usually abetted by the "friendly" plaintiff, recommending the appointment of a nominee of the management as sole receiver. In the appointment of receivers in ordinary bankruptcy, on the other hand, the most frequent criticism was that the judges used a list of political "availables".

Section $77 \mathrm{~B}$, in effect, gave Congressional approval to the theory of the friendly receivership by permitting the court to leave the debtor itself in possession of and administering its own assets, with the legal title of a trustee in bankruptcy. This practice has now been restricted to cases where the debtor owes less than $\$ 250,000$, where the expense of the fees of an independent trustee might prove unduly burdensome.

15. There is a twilight zone between the date of filing and the date of approval of an involuntary plan which bristles with unsolved questions. See Heuston, note 2 supra at I209-1210. 
Whether or not the change is salutary was bitterly argued before the Congressional committees considering the Chandler Act. ${ }^{16}$ The statutory solution-if it can be called that-is intended to assure to the court at least integrity in management during reorganization, if not detailed knowledge of the intricacies of the particular business, the way being left open to obtain the latter through the appointment of a cotrustee. ${ }^{17}$

The objection that political patronage might dictate trustee appointments is one that obviously cannot be overcome by statute, except, perhaps, by requiring the appointment of a public official or governmental body, such as the Securities and Exchange Commission. ${ }^{18}$ Attempts to overcome it, such as the rule in force for several years in the Southern District of New York, requiring the appointment of a particular trust company as receiver in all cases, raised such a storm at the bar that Congress ended the practice by statute. In the last analysis, the only sound criticism which can be levelled at the provisions of Chapter $\mathrm{X}$ in this regard is that there will be cases in which the statutory necessity for an independent trustee will saddle upon the estate an expense for which there may be no justification and may deprive the enterprise of the services of one or more individuals fitted by experience to guide its rehabilitation. If, in practice, the pressure of securityholder opinion, the reorganization bar and the S. E. C., holds to a minimum the element of political patronage in the appointment of independent trustees, the price would seem reasonable.

Once the receiver had been appointed, equity practice decreed that he.should concern himself solely with operations. ${ }^{10}$ Chapter $\mathrm{X}$, however, imposes some additional duties upon the independent trustee, the incidence of which must be immediately noted. He must promptly make a recommendation to the court as to whether or not an investigation should be made along the lines indicated above. The practice is a logical development from the Section 2I-a examinations conducted under the Bankruptcy Act of $\mathrm{I} 898$. Chapter $\mathrm{X}$ also requires the filing

16. Hearings before the House Judiciary Committee on $H . R$. 6439, 75th Cong., Ist Sess. (I937) I64, 280-2, 286, 303, 307-8, 328, 336-46, 343, 357, 358, 367; Hearings before the Senate Judiciary Committee on $H$. $R$. 8046, 75th Cong., $3 d$ Sess. (I930) Ir, 20-2I, 29-30, 48, 74, 90-9r, 93, 103.

I7. An interesting discussion of the functioning of the independent trustees in two important cases will be found in Gerdes, Recent Developments in Reorganizations under the Bankruptcy Act (1940) 26 VA. L. Rev. 999.

I8. This is contemplated by the Public Utility Holding Company Act of 1935, 49 StaT. 820 (1935), I5 U. S. C. A. \& 79K (f) (Supp. I939). The provision has not beep used, although in the important Associated Gas \& Electric Co. case, which is still pend ing in the courts, its use was seriously considered.

19. United States Mortgage \& Trust Co. v. Missouri, K. \& T. Ry., 269 Fed. 497, 50I (C. C. A. 5th, 192I): "A receiver does not represent the justiciable rights of the parties to the litigation of which he is receiver, but only the protection of the property in his hands as such, or the collection of that to the possession of which, as receiver, he is entitled." 
of schedules of assets and liabilities and lists of creditors and stockholders. Again, the origin is ordinary bankruptcy practice. ${ }^{20}$ The statutory requirement that a judicial determination be made with regard to an investigation of the debtor's affair's has, in the writer's view, one important advantage-to determine quickly the economic desirability of reorganization in the particular case. If there was one vice under Section $77 B$ and, to a lesser extent, in equity receivership, it was the institution of proceedings looking toward reorganization where liquidation only was justified. ${ }^{21}$

On the other hand, the most serious case against the investigation is built upon the contention that it may involve a time-consuming search for causes of action against management which are of doubtful validity or, if they exist, of doubtful collectibility. One of the most powerful influences in favor of expeditious reorganization is usually the management group. If they are to be concerned with defending themselves against claims of personal liability-and the existence of such claims is argued in many cases-they are not so likely, until these issues are disposed of, to concern themselves with reorganization. ${ }^{22}$ The trustee and the court must exercise restraint and an informed judgment to guide their decisions. The problem is human, not legal.

In his administration of the debtor's assets, the trustee in a reorganization proceeding is guided by the detailed instructions embodied in the court order appointing him. It may be a document many pages in length, ${ }^{23}$ the precedent for which lies in the railroad cases. The trustee is directed to take possession of the assets wherever located; his title thereto is confirmed; ${ }^{24}$ he is directed to continue the business and considerable detail in this regard will be set forth in any well drawn order; he will be given directions as to handling the debtor's funds, as to doing business on credit, as to continuing the services of registrars and transfer agents and as to many other points. The order will provide for a specific period of time within which the trustee may make his election as to the adoption or rejection of executory contracts and leases subject to extension of that time upon further order of the

20. See Heuston, note 2 supra at ra2r for a discussion of these provisions.

2I. See e. g., Judge Woolsey's comments in Muncipal Financial Corp. v. Bankus Corp., 45 F. (2d) 902 (S. D. N. Y. 1930) ; FINLETIER, op. cit. supra note 2, n. II.

22. See Foster, Conflicting Ideals for Reorganization (I935) 44 YALE I. J. 923; cf. Swaine, "Democratization" of Corporate Reorganizations (I938) 38 CoL. L. REV. 256; Gerdes, note I7 supra.

23. It is interesting to compare the form of order confirming the election of a trustee in ordinary bankruptcy, which consists of but a few lines. The comparison provides an illustration apposite to the fact that whereas ordinary bankruptcy was never gaited for the operation of a complex business under judicial supervision, equity receivership had developed this technique to a point where its principal features were thoroughly familiar to the petitioners in the field.

24. This may include the right and duty to take possession of assets in the hands of an indenture trustee. The point is debatable. See Heuston, note 2 supro at r227. 
court. Interference with the possession of the trustee by foreclosure of mortgages or otherwise will be specifically enjoined. ${ }^{25}$

Broadly speaking, the purpose of this order is to permit the trustee to operate the business of the debtor in substantially the manner in which it had been operated by the debtor itself without constant resort to the court or a special master for instructions on relatively unimportant points. The trustee will, however, if well advised, request instructions from time to time where any fundamental change of business or financial policy is involved; for instance, where it is proposed either to pay or to default on a maturing installment of interest on an underlying bond issue-to contest what is considered to be an excessive tax assessment-to establish a line of credit or to change credit terms to customers.

Further, the power to borrow money upon trustees' certificates has been clarified by the acts. Under equity practice, the power to displace the lien of an existing mortgage was entirely unclear; except in railroad and public utility cases for preservation, as distinct from operation or betterment, of the debtor's property. Under Section $77 B$, while the trustee had authority to borrow money and to issue certificates therefor upon such terms "as may be lawful in the particular case", there remained doubt as to whether existing liens could be displaced. Chapter $\mathrm{X}$ gives the judge clear power to permit borrowing on certificates for any purpose which he deems proper, and provided adequate notice be given, seems to permit displacement of liens regardless of the nature of the enterprise. ${ }^{28}$

Other mechanical steps will also be taken. Landlords may attempt to force the issue as to the acceptance or rejection of their leases. Holders of executory contracts may take similar action. Indenture trustees may seek to impound income for the benefit of their bondholders. ${ }^{27}$

25. This provision is, of course, a departure from the equity practice, where the court had no authority to enjoin a mortgage foreclosure beyond the point when the indenture trustee applied for permission to institute it. MacGregor v. Johnson-CowdinEmmerich, 3I F. (2d) 270 (C. C. A. 2d, I929); Gay v. Hudson River Electric Power Co., 184 Fed. 689 (C. C. A. 2d, I9Ir).

26. The issues are clearly drawn in the opinion of Evans, C. J., in In re Prima Co., 88 F. (2d) 785 (C. C. A. 7th, 1937) holding in favor of priority under Section 77 B.

27. The situation here deserves some comment. Under equity practice, income did not accrue to the indenture trustee until application had been made for the appointment of a foreclosure receiver. FINLETTER, op. cit. supra note 2, at 333-343; IsRAELS AND KRAMER, note 6 supra passim. By the same token, expenses incurred in an equity proceeding or a loss incurred in operations prior to the application were not chargeable against the mortgaged property. MacGregor v. Johnson-Cowdin-Emmerich, 39 F. (2d) 574 (C. C. A. 2d, 1930).

The question of the date at which a mortgagee's application for the impounding of income in a raorganization proceeding shall be effective, if application be not made at the time of the approval of the original petition, has not been settled. The decisions are in conflict. See e. g., In re Wakey, 50 F. (2d) 869 (C. C. A. 7th, I931) which probably represents the more logical view, making the application effective as of the 
The reorganization acts have not dispensed with the necessity for the litigation of conflicting claims of creditor groups. If controversies exist as to priorities between groups of secured creditors, or between secured and unsecured creditors, prompt steps should be taken to bring them to a head. Intelligent compromise can more often be made after contentions of the parties have been subjected to the cold light of trial procedure and proof than while they remain in the realm of pure argument. The more complex the corporate structure, and the larger the enterprise, the more likely it is that situations of this sort may arise. In the writer's experience, counsel for junior interests, particularly for unsecured creditors, have in many proceedings been ignorant of or slept upon their clients' substantial claims to unmortgaged assets, the existence and value of which might substantially improve their trading positions when the stage of plan formulation is reached. ${ }^{28}$

Chapter $\mathrm{X}$ contemplates that an order shall be made requiring the proof of claims and interests by creditors and stockholders. ${ }^{29}$ Experience dictates that no such order should be presented at an early stage of the proceedings in contradistinction to ordinary bankruptcy practice where a statutory six months' time limit is imposed. The reason is that Chapter $X$ departs from Section $77 B$ by making specific provision that votes for or against a plan of reorganization shall be counted only if and when the voting securityholder has proved his claim. $^{30}$ If an order be submitted at an early stage of the proceedings and a large number of claims proved, securityholders' inertia may later block approval of a plan. Where claims are proved only in conjunction with votes on a plan, whether those votes be negative or affirmative, this cannot occur. This technique is, therefore, recommended at least as to indenture securities where the indenture trustee's blanket claim

date of the original petition. Contra: In re Brose, 254 Fed. 664 (C. C. A. 2d, I918) The concomitant problem of whether or not expenses incurred prior to the date of the application may be imposed upon the mortgaged estate does not seem to have arisen. As a practical matter, it will probably never arise except where reorganization effort fails and liquidation ensues.

Undoubtedly the present-day tendency is for indenture trustees, particularly in view of the new and stricter standard of vigilance imposed upon them after default by the Trust Indenture Act of 1939, 53 STAT. II49, I5 U. S. C. A. \$\$77 aaa-bbb (Supp. 1939) to seek impromptly to impound income. However, if the debtor's operations are being conducted at a cash loss, or its income is insufficient to meet operating expenses and taxes, prompt application to impound income may be unwise. It is possible that by refraining from so doing, the indenture trustee may preserve to itself a position similar to that sanctioned by the MacGregor case, supra. On the other hand, a mere appearance by counsel may be sufficient to impose the loss on the mortgaged property.

28. The limitations on the scope of corporate mortgages, particularly where consumable property is involved, are not apparently sufficiently well known to the Bar. See Brown v. Leo, I2 F. (2d) 350 (C. C. A. 2d, I926); MCCLELLAND \& FisHER, LAw of Corporate Mortgage Bond Issues (I937) c. 8 . But $c f$. the Pennsylvania cases which reach a contrary result.

29. Chapter X requires "proofs of claim" by creditors. The language is, unfortunately, technical. See Heuston, note 2 supra at 1222.

30. Chapter X, § 179. 
will protect the right to participate under the plan,, 31 and as to stock where a list of holders can be made to perform the same function. If contested claims are anticipated, they will usually be those of landlords or contingent or trade creditors. Proof of such claims can be required by separate order.

Adequate representation of parties in interest before the court on administrative questions (as distinct from plan formulation) has always been a serious problem. Under equity practice, the technicalities of a foreclosure suit were rigidly observed. The parties before the court, as of right, were the complaining creditor (who usually dropped into a minor position almost immediately), the defendant (which, as such, had little, if any, voice in a creditors' proceeding looking toward its dismemberment), the indenture trustees and the receivers. Bondholders' committees often appeared, but no committee, no matter how high a percentage of the issue it represented, could intervene over the objection of its indenture trustee, unless it could show a conflict of interest or that its trustee was derelict in its duty. ${ }^{82}$

Section $77 \mathrm{~B}$ gave to all creditors and stockholders the right to be heard on the question of the permanent appointment of any trustee and on the proposed confirmation of any plan and "upon filing a petition for leave to intervene, on such other questions arising in the proceeding as the judge shall determine". ${ }^{38}$ This provision did not work too well. Petitions for leave to intervene were commonly filed by every individual creditor, stockholder or committee which wished to express itself through counsel in the proceeding. Two distinct judicial practices developed in dealing with these petitions. One school of thought permitted interventions freely, expressing the view that to do so gave no right which did not exist without intervention and that the fact of intervention was clearly no ground for an allowance of compensation and disbursements out of the estate. The other view required affirmative showing of a right to intervene, upon the theory that without that right, no allowance could be granted nor appeal taken from any order except, perhaps, on the two subjects specifically mentioned in the statute. The epitome of the views of this school of judicial thought is perilously close to the equity receivership practice with an added element-that of diligence in appearance on the scene. ${ }^{34}$

3I. Chapter X, \& I98.

32. Palmer v. Bankers Trust Co., 12 F. (2d) 747 (C. C. A. 8th, I926). This doctrine was a convenient means of restricting active participation in receiverships to majority interests.

33. $\$ 77 \mathrm{~B} \mathrm{C}(\mathrm{Ir})$.

34. See e. g., In re Paramount Publix Corp., 85 F. (2d) 588 (C. C. A. 2d, 1936), in which the court stated that compensation should be denied to any representative of securityholders if a committee were already in the field, and was not somehow shown to be "inadequate" in its representation of the issue. A district court rule was suggested to deal with the point. 
Chapter X is clearer. Any creditor or stockholder may be heard at any time upon any question, and indenture trustees are specifically given the same right. ${ }^{35}$ Intervention has been reduced to what should be its major purpose-to give the right to receive notice in advance of motions and other steps to be taken in the proceeding. Under Section 207, the judge may, for cause shown, permit a party in interest to intervene generally, or with respect to any specific matter and enter orders designating the matters with respect to which, the persons to whom and the form and manner in which notice shall be given. $\mathrm{He}$ may also invite the S. E. C.'s active participation in the proceeding, or the Commission may appear on its own motion with his approval. ${ }^{86}$

It seems to the writer that prudence dictates general interventions by all indenture trustees and by at least one committee, large holder or other representative of each class of securities. Where possible conflicts of interest or clear differences of view going beyond any single issue appear among securityholders of the same class, greater liberality in this regard seems indicated. Notice to all is a cure for many evils.

\section{The Reorganization Plan}

\section{A. Its Formulation}

The third stage-the process of formulation of a plan of reorganization-may be likened to a poker game. The chips in the center of the table (the debtor's property) must be divided in accordance with the cards (claims) held by the players (creditors and stockholders) who have each contributed to the "pot". The problem is essentially one of evaluation of the relative priorities of those claims, to which must be added the elements of the size of the pot and its eventual earning power.

Skill at the game is of substantial importance. Throughout the history of reorganization, some individual or group of individuals representing one or more classes of securityholders has, regardless of his or its position in the particular proceeding, largely guided, if not dominated its conduct and the formulation of a plan, by reason of general intelligence, legal knowledge and experience at plain "horse-trading".

35. Chapter X, § 206.

36. Apparently, however, the S. E. C., could intervene in the public interest without such invitation. Securities \& Exchange Commission v. United States Realty \& Improvement Co., 60 Sup. Ct. 1044 (1940). The Commission does not participate actively in all cases. Where cases were begun under Section $77 \mathrm{~B}$, the Commission seems to have been reluctant to come very far into the picture, even where courts have made Chapter $\mathrm{X}$ applicable. In cases where reference of the plan is not mandatory under Chapter $\mathrm{X}$, the debtor's liabilities being less than three million dollars, the Commission's decision as to whether or not to participate is probably dictated by the amount of public investor interest which it considers present. Where reference is mandatory, active participation usually follows. 
No statutory provision that can be drawn, save one providing for the imposition of a plan conceived in vacuo by the court or an administrator, ${ }^{37}$ could change the fundamental nature of this process, nor was it intended that it should be essentially changed.

The principal developments under the reorganization acts have been three: first, to take from the majority senior creditors their dominant position of being able to force foreclosure, cutting off all junior interests, at any moment when they could agree among themselves; second, to bring the bargaining process in some measure into the open; and third, to deprive the bargainers of the opportunity to seek even theoretical rank and file support for the views they may advance in the trading process.

The first of these developments is not traceable entirely to the statutory provisions, though they were influential in producing it. Under equity practice, the foreclosing senior creditors had to be satisfied-or they would not permit their juniors to participate in the purchase. The burden rested on the junior interests to justify their participation in the plan by establishing the existence of unmortgaged property of substantial value. This accomplished, the equity rule for the proving of secured claims at their full amount, without deduction, ${ }^{38}$ often made the junior position still difficult of defense. The sale was the final test. It was made at auction, and if the seniors would not bid with credit on their indebtedness, the juniors were confronted with the problem of raising cash with which to bid-often an impossible task. Practically, therefore, the juniors took what they were offered.

Under $77 \mathrm{~B}$, the burden shifted. The debtor was often in possession. It could propose a plan without creditor or stockholder action. The rule for the proof of secured claims was less onerous on junior interests, requiring deduction of the value of security as in ordinary bankruptcy. ${ }^{39}$ The Act required consent of two thirds of each class of creditors for confirmation of a plan and of majorities of each class of stock. The latter might be dispensed with upon proof of insolvency ${ }^{40}$ but in a vast corporate enterprise that proof was difficult. ${ }^{41}$ Not until some time after the Act did the Supreme Court uphold a plan which eliminated junior creditors upon the ground that their

37. Cf. the power of the President under the N. I. R. A., to "impose" a code upon a recalcitrant industry.

38. Merrill v. National Bank of Jacksonville, I73 U. S. I3I (r899).

39. $\$ 77 \mathrm{~B} \mathrm{~b}$ (10).

40. $\$ 77 \mathrm{~B} \mathrm{~b}(4)$.

$4 \mathrm{r}$. An early case under $\$ 77 \mathrm{~B}$ will serve to illustrate the point. In re Republic Gas Corp. (S. D. N. Y. I935), involved the valuation of natural gas reserves. Stockholders successfully contended that no estimate of the value of those reserves could be found sufficiently accurate to justify an adjudication of insolvency. The case is unreported, except for an opinion on allowances appearing at 14 F. Supp. 703 (S. D. N. Y. 1935). 
claims had no value. ${ }^{42}$ Debtors' counsel argued vigorously for the "composition theory" of reorganization in bankruptcy, that the acts were "for the relief of debtors", etc. ${ }^{43}$ These contentions have finally been rejected by the Supreme Court. ${ }^{44}$ Their merit is not within the purview of this article, but they serve to emphasize the point that under the reorganization acts, as distinct from equity practice, the junior creditor and the stockholder are entitled to participation in the plan until proven not to be.

To return to the poker analogy, the key lies, of course, in valuation of the "pot"- -at best a difficult process. ${ }^{45}$ The I935 Amendment to Section 77 contains arresting language on this subject:

". . . The value of any property used in railroad operation shall be determined on a basis which will give due consideration to the earning power of the property, past, present, and prospective, and all other relevant facts. In determining such value only such effect shall be given to the present cost of reproduction new and less depreciation and original cost of the property, and the actual investment therein, as may be required under the law of the land, in light of its earning power and all other relevant facts."

However, it is not demonstrable that an earnings basis of valuation has been controlling in the railroad cases, except in limiting new capitalization in fixed income bonds to an amount service upon which would be adequately covered in depression years and allocating such bonds among securityholders on the basis of studies showing so-called "segregated earnings" of various portions of the road upon which the particular issue may be a prior lien. Income bond and stock capitalizations have reached much higher figures within the maximum fixed by the reports of the Interstate Commerce Commission's Valuation Division on "Elements of Value". ${ }^{46}$

In non-railroad cases, the problem is at once less complex. The element of conflicting lien claims is usually not present, though there may be some question as to the contribution to earnings fairly attributable to unmortgaged assets. On the other hand, industrial property is not always so specialized as railroad property and may be

42. In re 620 Church Street Bldg. Corp., 299 U. S. 24 (I936).

43. See e. g., In re Spokane International Ry., Reorganization, 228 I. C. C. 387, Finance Docket No. I0,I3I (I938), particularly the briefs of the Debtor and Mr. Ballard, as amicus curiae.

44. Case v. Los Angeles Lumber Products Co., 308 U. S. I06 (I939).

45. BONBRight, THE VALUATION OF PROPERTY (I937).

46. Generally speaking, this has resulted in the elimination of stockholders' interests. However, a comparison of the percentage earned on Commission approved capitalizations in various plans on the basis of the average earnings of certain roads from 1926 to 1939 has been estimated as varying from 1.8 to $4.9 \%$, averaging $3.3 \%$. (Petition of the Ecker Committee, In re St. Louis-San Francisco Ry. Reorganization, I. C. C. Finance Docket No. I0,008, Sept. 3, I940.) 
demonstrably saleable on a higher basis than an earnings valuation would show. ${ }^{47}$ Yet it seems that there is discernible in the S. E. C. advisory reports on plans under Chapter $\mathrm{X}$ a clear tendency to lean heavily upon capitalization of earnings as the most reliable valuation base.

Apart from the soundness of the theory, discussion of which is foreign to this article, the procedural advantage of such a relatively simple yardstick to measure the right of junior creditors and stockholders to participate and to enable the senior interests to meet the burden placed upon them by the acts is obvious. The danger is that the future potentialities of businesses whose earnings are hypersensitive to general conditions may be underestimated.

The second and third points of change mentioned above follow more clearly from the reorganization acts themselves and, particularly, from Chapter $X$. The focussing of responsibility in the trustee for the recommendation of a plan to be considered by the court seems, in a sense, a compromise between the equity procedure, where, as pointed out above, but one plan might be considered with consequent disadvantage to the objector, and that under Section $77 \mathrm{~B}$, where proposal of a complete new plan by a single creditor or stockholder, as an "amendment" to a pending plan, effectively nullified the statutory percentage requirements for proposal by creditors or stockholders, once $a$ plan was before the court. The trustee's plan will have the advantage of having been worked out after statutory notice to all that suggestions may be submitted, ${ }^{48}$ perhaps after informal hearings or conferences presided over by the trustee and open to attendance by all parties in interest. When it is reported to the court for consideration, time may be saved by the trustee being prepared to explain his rejection of proposals advanced for the second time.

The place of the S. E. C. in plan formulation is more difficult to evaluate. Technically, unless it has intervened in the proceeding, it has no position until one or more plans be submitted for advisory report. Practically, however, its position is a powerful one calling for the exercise of great restraint. The Commission's policy has apparently been to make the services of its staff available to trustees and other participants in Chapter $\mathrm{X}$ proceedings when such services have been requested, seeking to guide rather than to dominate the plan formulation process, primarily by raising, without the expression of any view, what seem to the staff to be debatable issues.

47. Cf. a real estate case, or that of a motion picture theatre where ownership, management and availability of film are often closely intertwined, e. g., In re Roxy Theatres Corp. (S. D. N. Y. 1937) (unreported).

48. Chapter X, \& I67 (6). 
Chapter X specifically forbids solicitation of assents to any plan prior to its approval by the court and the filing of the S. E. C. advisory report, if any, unless the judge shall specially sanction such solicitation. ${ }^{48}$ The Commission early adopted a policy of opposition to any such application. The problem thus becomes in even greater measure one of personnel. Who is to speak, in the plan formulation process, for the rank and file whose rights and interests are to be dealt with?

No better method of securityholder representation in reorganization proceedings has yet been found than the committee system. The origins of that system under equity receivership practice are well recognized. Underwriting houses responsible for the flotation of the debtor's securities, being advised of the existence or imminence of a default and consequent receivership, formed committees from among their personnel or customers to represent the various classes of securities, and employed counsel who prepared deposit agreements under which the securities were delivered to a depositary whose negotiable certificates of deposit, or receipts, were issued therefor.

The powers of committees under these agreements were extremely broad. They could, and did, customarily, pledge the deposited securities for substantial loans to pay committee expenses and sometimes compensation to committee members, or for the use of the office facilities of one or more underwriting houses. The committee's expenses and compensation were a prior lien upon the deposited securities and the agreements were commonly so drawn that the committee itself had full discretion in fixing its own compensation and in passing upon the compensation of its agents, counsel and other employees. The system was undoubtedly abused. ${ }^{50}$

If the company were reorganized, the depositing securityholder had no direct concern with these expenses. They were paid by the reorganized company (outside of the jurisdiction of the court) as an incident to consummation of the plan. ${ }^{51}$ If they were high, the working capital position of the reorganized company suffered accordingly. If, however, reorganization did not take place, an anomalous situation was created. The cash proceeds of the sale of the liquidated enterprise would be distributed on the deposited securities to the committee which would deduct a pro rata share of its expenses and, perhaps, compensation, while the non-depositing holder would receive a higher dividend.

49. Chapter X, § I76.

50. Bills of particulars will be found in many places, e. g., Lowenthat, THE INvestor PAYS (1933) Report on the Study and Investigation of the Work, Activities, Personnel and Functions of Protective and Reorganization Committees, published by the Securities \& Exchange Commission from 1936 to 1940.

5I. FINLETTER, op. cit. supra note 2 at I7; GERDES, op. cit. supra note 2 at $60-6 \mathrm{r}$. Cf. United States v. Chicago, Milwaukee, St. Paul \& Pacific R. R., 282 U. S. 3II (I93I). 
The deposit agreement also customarily provided that depositors might be bound to assent to a plan of reorganization by published notice of a resolution of the committee adopting the plan (copies being available upon application to the depositary), plus the expiration of, perhaps, twenty days from the date of that notice, within which the depositor might withdraw his security upon payment to the depositary in cash of his pro rata share of the committee's expenses and compensation, at a figure fixed arbitrarily by the committee.

These practices led to an unwillingness among investors, nurtured by their advisors, banks, investment services, brokerage houses, etc., to deposit their bonds. An immediate market differential between certificates of deposit and actual securities would appear because of the fear of assessment for withdrawing the security. Advice was freely given to investors not to deposit their securities with any committee until a plan had actually been promulgated and its terms made public. If then, the securityholder wished to accept that plan, he might be advised to deposit, but not otherwise. Resistance to the plea for deposits, combined with the necessity for payment in cash to the dissenting securityholders, made difficult the task of assembling sufficient support to put through a plan under equity practice. Perhaps, even the representation necessary to instruct the indenture trustee might not be obtained.

Section $77 \mathrm{~B}$, by eliminating the sale as a method of consummating a plan, did away with the necessity for the committee as purchaser at a sale to have physical possession of the bonds it represented, in order to present them in part payment of the purchase price. The Securities Act of 1933 required the registration of certificates of deposit as issues of new securities where they were offered, as was usual, at the early stages of a receivership or reorganization proceeding, before a court could pass upon their terms. Committees, therefore, no longer sought deposits. They sought proxies or powers of attorney giving them the right generally to represent the securityholder in the proceeding which were not, of course, registerable as "securities". Under these proxies, no borrowing for committee expenses or fees for withdrawal were possible. In large measure, however, the harm had already been done. Although no precise statistics are available, it is believed that, generally speaking, committee representation in recent years has been much less substantial than before the reorganization acts. Despite the removal of the possible assessment for withdrawing the securities and the introduction of court supervision over fees and expenses, there remains a general feeling among securityholders that unless and until a specific plan is submitted for their views, they may 
in some manner prejudice themselves by authorizing a committee to speak for them.

By Section $77 \mathrm{~B}$, the reorganization court was given specific power over the terms of deposit agreements which it could ignore, amend or alter at will and all committee compensation and expenses in connection with plans consummated under the Section required specific approval of the court. ${ }^{52}$ The provisions are carried over and added to in Chapter X.s3

At the time when the Chandler Act was pending in Congress, there was also pending the Lea Bill for the regulation of the solicitation of proxies, deposits or assents. The text of Chapter $\mathrm{X}$ apparently contemplated the enactment of this bill for it requires that no agent, indenture trustee or committee purporting to represent creditors or stockholders shall be heard or allowed to intervene until the court has been satisfied that "they have complied with all applicable laws regulating the activities and personnel of such persons". ${ }^{54}$ In addition, Chapter $\mathrm{X}$ provides that any attorney for creditors or stockholders must, before he can be heard, file with the court a statement setting forth the names and addresses of his clients, the nature and amounts of their claims or stock and when the same were acquired, unless they were acquired more than a year prior to the fling of the petition. Protective committees or any other person purporting to represent more than twelve creditors or stockholders and every indenture trustee must file a statement including a copy of the instrument empowering him to act, the facts in connection with the selection or employment of such person, committee or trustee, the amounts of claims or stock owned by such person, committee member or indenture trustee when employed or organized, the dates of acquisition, the prices paid, the amounts sold and a showing as to amounts of claims or stock represented "with an averment that each holder of such claims or stock acquired them at least one year before the filing of the petition or with a showing of the times of acquisition thereof"..55

These provisions of Chapter $\mathrm{X}$ are obviously aimed at attorneys' appearances in court attacking the plan or the principal interested parties, or both, but successfully evading all demands that they state

52. $\$ 77 B$ b (10), c (9).

53. Chapter $\mathrm{X}, \S \S 2 \mathrm{II}-2 \mathrm{r} 3$.

54. Chapter X, § 213. The Lea Bill (H. R. Rep. No. 6968, 75th Cong., Ist Sess., I937) failed of passage. There are, however, several state laws requiring qualification of committees before some state body before they can function. E. g., CAL. GEN. LAws (Deering, 1937) 3815. In many cases, the Proxy Rules of the Securities and Exchange Commission will also apply and must, presumably, be complied with to satisfy the requirements of Section $2 \mathrm{r} 3$.

55. Chapter X, §§ 2I0-2Ir. 
exactly whom they represent, the amounts of securities owned by their clients and when those securities were acquired. ${ }^{56}$

Provided that all of these requirements have been complied with, Chapter $\mathrm{X}$ gives an undoubted right to committee members to receive compensation and reimbursement of their expenses out of the estate upon allowance thereof by the court.

However, it would seem that statute cannot alone rehabilitate the committee system. Effective securityholder representation is dependent first upon the willingness of the average securityholder to grant to a committee or other representative authority to participate in the proceedings and in the formulation of a plan on his behalf, and second, upon the willingness of experienced and honorable men to serve as members of committees. The first issue has not, it is felt, been successfully met by the statutory provisions, nor can it be. It is arguable that securityholders will not again be willing, in large number, to entrust their fortunes to protective committees until the record of protective committees justifies it. The statutory provisions summarized above are an attempt to meet the second issue, but in a negative fashion, by making it difficult for self-seekers representing no real interest, or having some past connection with the particular securities or the debtor, to solicit proxies, by requiring full disclosure in advance.

Undoubtedly, the red tape involved in the organization of committees to function in proceedings under Chapter $X$ has had a deterrent effect. The principal deterrent, however, seems to be one the remedy for which lies not with Congress but with the courts. Unfortunately, much of the criticism of reorganization committees has been based upon the fees paid to their members. The result has been a public impression that committee members and, indeed, all counsel participating in reorganizations, are bound to be handsomely paid and an equivalent conviction among experienced practitioners that compensation will probably be inadequate, if not niggardly. The I935 amendments to Section 77 embodied a congressional policy forbidding the payment of compensation to committee members in railroad cases. The result has been an unfortunate one. Since that enactment, there have been practically no committees formed to represent railroad securityholders. The insurance companies, savings banks and other institutional holders of railroad securities have organized for their own protection, but their interests are not and cannot be precisely similar to those of the smaller investor. They usually hold more than one issue and are thus interested in a reorganization plan which makes provision for all issues and in the compromise of controversies which may seriously injure the

56. Heuston, note 2 supra at 1225. 
rights of holders of one or more issues, to the advantage of another. These institutional holders have made no bones about the positions they have taken. They have publicly stated that they do not act in reorganization proceedings as fiduciaries for anyone except their policyholders or depositors. ${ }^{57}$ Thus, the interests of the individual securityholder are left unrepresented except, in the case of indenture securities, by the indenture trustee which has no beneficial interest in the outcome and has not been encouraged by the courts. ${ }^{68}$

Reorganization courts in recent years have been all too anxious to make a record for economy in the administration of estates. At the time when applications for allowances are made, the work has been done, the plan has been confirmed, the property is about to be transferred to the reorganized company,-what is the cost to be? It is believed that courts have far too often yielded to the pressure of uninformed public opinion that the cost of reorganizations in general is too high and, thus, in effect, forced committee members and others, ex post facto, to render services for what can only be described as wholly inadequate and meager compensation. ${ }^{59}$ They will, naturally, be slow

57. Such groups are organized pursuant to subsection (p) of Section 77. Eminent counsel for a large insurance company has said:

“. . But this further effect it [the formation of groups of institutional securityholders] has and will have: more and more, single-minded insistence upon the rights of any particular class of securityholders, their priorities, and the security to which they are entitled, will be subordinated to the inability on the part of all to do other than compromise those rights in order to put through a plan. The tendency of the past to compromise will be unduly accentuated. Priorities which have been bought and paid for will be to an extent further diluted in the interests of compromise and expedition. This is true because there will be no one responsible committee looking after any particular class but all will be talking together as the holders of various classes. In the sense of cooperatively working together, this is fine. In the sense of upholding the priorities which have been paid for in high prices and low yields, it is bad." Shanks, The Law of Railroad Reorganization as Affecting Institutional Investors (a paper read before the Association of Life Insurance Counsel, December 3, I935) 333.

58. An apt illustration is afforded by the positions of the group of insurance companies and the group of mutual savings banks in the reorganization proceedings affecting the New York, New Haven \& Hartford Railroad Company, now pending before the Interstate Commerce Commission. The insurance group holds approximately $14 \%$ of the New Haven First \& Refunding bonds (the largest system issue). The savings bank group holds approximately the same percentage. The latter group, however, also holds approximately $49 \%$ of the First Mortgage bonds of Old Colony Railroad Company, the lease of whose properties has been rejected by the New Haven Trustees. One of the most serious questions confronting the Commission and the Court in the New Haven case is whether or not the Old Colony lines should be included in the New Haven system as reorganized. The two groups have taken diametrically opposite positions on the point, each position logically dictated by the holdings of the group. The indenture trustee of the New Haven First \& Refunding Mortgage has filed briefs differing in view from both the groups, but its position is not an enviable one. Save for an independent committee representing about $\mathrm{I} \%$ of the issue, it must perforce speak for a silent majority ( $70 \%$ or more holding over $\$ 100,000,000$ principal amount of bonds) with all the handicaps of a trustee bound to take account of the views of the two largest holders of its indenture securities.

59. An extreme instance is the case of In re Detroit International Bridge Co., III F. (2d) 235 (C. C. A. 6th, I940), where the District Court, apparently under newspaper pressure, made allowances to the committees and counsel not only far below the amounts asked, but far below those recommended by the S. E. C. An appeal was taken and the allowances substantially increased, but not even to the S. E. C. figures. 
another time to take on the burden, leaving it to less experienced, capable or qualified personnel.

Where committee members are affiliated with underwriting houses, the argument can be made that on the basis of moral responsibility, the level of compensation should be low. Where they are large securityholders, the argument can be made that they are protecting their own interests for which they would not be compensated out of the estate except for their willingness to undertake the protection of others similarly situated; that therefore, here too, the level of compensation should be low. ${ }^{60}$

Inconsistently enough, when either of these situations obtains, the argument is often heard that the committee represents no real or substantial interest; that compensation should, therefore, be held down in order to discourage self-seeking committees.

Of course, these arguments are extremes. They are not always voiced, nor have they been by any means universally heeded by the courts. However, unless and until some better means be devised, the committee system should be fostered and encouraged. Only through it can representatives of substantial groups of securityholders come before the court clothed with the fiduciary responsibility which they should bear. One may venture the prediction that with the continued requirements for full disclosure of prior interest, as required by Chapter $\mathrm{X}$, the quality of committee representation of securityholders will improve, as the federal courts hew more nearly to the line that the laborer, particularly where he shares none of the moral responsibility for the debtor's difficulties, is worthy, not of excessive, but of reasonable hire.

The indenture trustee is in a somewhat similar situation. From the equity proceeding, where the indenture trustee was the major litigant, the pendulum swung completely in the other direction under 77B. Many reorganization courts took the view that the indenture trustee, as a mere stakeholder, had substantially no place in reorganization proceedings and should be compensated meagerly, if at all. But the indenture trustee is mentioned many times in the text of Chapter $X$ which apparently contemplates that it shall take an active part in the proceedings. The Trust Indenture Act of $1939^{61}$ seems to contemplate

60. In one recent case, it was argued that the largest securityholder, which had proposed the plan and borne the burden of conducting the proceedings, should not be compensated at all because it was protecting its own interests; that regardless of the prospect of compensation from the estate, it would nevertheless have undertaken and carried through the task. The contention was rejected by the Securities \& Exchange Commission and the court. In re Radio-Keith-Orpheum Corp. (S. D. N. Y. 1940) (unreported).

6r. 53 STAT. II49, I5 U. S. C. A. §§77aaa-bbb (Supp. 1939); note 25 supra. 
the same thing. Under these circumstances, a reversal of the trend seems indicated. ${ }^{62}$

\section{B. Court Consideration}

At least until the Supreme Court dicta in the Coriell and Flershem cases ${ }^{63}$ indicated the necessity for full court consideration of a plan regardless of the preponderance of securityholder support for it, the hearings on the plan under equity procedure were likely to be somewhat perfunctory. Often, they consisted purely of argument. Section $77 \mathrm{~B}$ made no different requirement and under it, two circuit courts of appeals held, despite the dicta, that the burden of proof in favor of the fairness, equity, and feasibility of a pending plan was largely met by the fact that it had the requisite securityholder support. ${ }^{64}$

The Supreme Court emphatically rejected this doctrine and reaffirmed the views expressed in the Coriell and Flershem opinions by its recent decision in Case v. Los Angeles Lumber Products Co. ${ }^{65}$

The court must, therefore, form its independent judgment of fairness, equity and feasibility after full hearing upon all available evidence. In the writer's view, this requires not only argument, but actual proof. The published advisory reports of the S. E. C. give some indication of the nature of such proof-indeed, it is a fair assumption that the Commission, rather than the courts, has had a major share in outlining the requirements and in seeing to it that they are met. A complete history of the business and its financing seems first called for; then, some attention to its management and operations; the probable causes of its troubles; its physical assets and financial condition; its place in the economic sun, generally and in the particular industry; its earnings, past, present and estimated for the future.

62. The language of Chapter $X$ is somewhat similar to that of Section 77 under which the problem has arisen, particularly in connection with compensation to indenture trustees, of determining whether or not services rendered directly benefited the debtor's estate, as distinct from the particular class of creditors represented, and there has been a tendency in some decisions to refuse compensation for the latter type of service: e. g., services in connection with a controversy between conflicting creditor groups as to their respective priorities. The conduct of this type of controversy is, in the writer's view, often one of the most important functions of an indenture trustee or a committee. A broad view would include such services within the statutory language. This construction was adopted by District Judge Hincks in a recent decision in In the Matter of New York, New Haven \& Hartford R. R. (D. Conn. 1940) (unreported). Contra: Straus v. Baker Co., 87 F. (2d) 401 (C. C. A. 5th, I937) semble. The problem is succinctly stated and the issues drawn in the testimony of Alfred $N$. Heuston, Esq. Hearings before the Special Sub-Committee on Bankruptcy and Reorganization of the Committce on the Judiciary of the House of Representatives on S. I869 (The WheelerTruman Railroad Reorganization Bill), 76th Cong., Ist Sess. (1939) 389 et seq.

63. Sce First Nat'l Bk. v. Flershem, 290 U. S. 504, 525 (1934); National Surety Co. v. Coriell, 289 U. S. 426,436 (I933).

64. Downtown Inv. Ass'n. v. Boston Met. Bldgs., Inc., 8I F. (2d) 314 (C. C. A. Ist, 1936); In re New Rochelle Coal and Lumber Co., 77 F. (2d) 881 (C. C. A. 2d, 1935).

65. 308 U. S. 106 (1940). 
Valuation evidence is vitally necessary and here it would seem from the published reports that, as pointed out above, emphasis upon valuations, based primarily, if not entirely, upon earnings, is in the ascendant. Finally, it seems highly desirable that some person, perhaps the trustee or member of a committee appearing in support of the plan under review, testify to the reasoning by which the adjustments of rights embodied in the plan between the various classes of securityholders were arrived at.

In addition to embodying certain requirements and prohibitions as to the contents of a plan, its course from preparation to consummation is carefully charted by Chapter $X^{68}$ Up to the point of submission to the S. E. C., the trustee or the proponent of the proposed plan or plans (for more than one may be considered at the same time) ${ }^{67}$ must assume the burden of producing the evidence. If it be the trustee, he may become anomalously an advocate between contesting groups. The Commission holds no hearings and has adopted a policy of not filing advisory reports in all cases in which it participates, but only in those considered to involve a public investor interest, or referred to it under the mandatory provisions of Chapter X.

Once the Commission report is filed (or the Commission advises that it will not file one), the judge will determine which plan or plans comply with the Act, approve them and order them sent to those entitled to vote thereon, together with his opinion and the S. E. C. report, if any, or summaries thereof. Thus is the fourth stage-that of consummation-reached.

\section{Consummation}

Under equity practice the mechanics of property transfers were, perhaps, more complex than the now permitted procedure of handing the debtor back its property, but the assumption of reorganization expense (particularly committee fees and disbursements, as distinct from compensation of receivers and indenture trustees), the creation of the new company, and the issuance and distribution of its securities were extra-judicial functions. After confirmation of the sale, the court was concerned merely with special masters' and receivers' reports and accounts ending finally in an "order of distribution" which, for practical purposes, directed only the making of the payments to dissenting creditors. This process has been materially changed by the reorganization acts.

66. A succinct summary of Chapter $\mathrm{X}$ from both these points of view is contained in Heuston, note 2 supra at 1213-1217.

67. Chapter X, \& I72. 
Section $77 B$ removed much of the fictional aspect of this procedure, but added to the court's burdens those of approving new indentures, supervising the mechanics of distribution of new securities and making allowances to any and all persons claiming to be entitled to compensation from the estate, including committees and their counsel and even individual securityholders.

Chapter $\mathrm{X}$ adds to the fourth stage some uncertainty as to securityholder acceptance of the plan or plans submitted to them. The policy of the statute in forbidding the solicitation of acceptances until the fourth stage may be said to be somewhat paternalistic. It requires acceptance of the thesis that it is better to have no expression of securityholders' views in advance of court and Commission consideration of a plan, than to have an expression which may have been sought or influenced by self-seeking interests, the disclosure of which ${ }^{68}$ is not considered sufficient without the protective cloak of the court's affirmative view and the Commission's advice pro or con as the case may be.

Securityholder inertia is largely discounted by the limitation of the right to vote to those who have proven their claims. ${ }^{69}$ From a policy standpoint, however, the vote should be an intelligent one-and the judicious use of simple language and summaries of court opinions and the Commission reports is a prerequisite. Otherwise, the tendency to throw a voluminous dossier, bristling with tables and figures, into the wastebasket may prevail and the fate of the plan be decided by a very small number of the real parties in interest.

How far court and Commission approval or Commission dissent on the fairness of particular plans have weighted securityholder action is a question difficult of accurate analysis. ${ }^{70}$ Fundamentally, the problem is human and psychological. No matter what the statutory set-up, so long as securityholder action is sought as the court of last appeal, the process for expression of those views should be made simple and such expression encouraged. One thought may be worth consideration and is possible under the present text of Chapter X. It may prove useful to permit solicitation at any point in the proceeding, at least on particular issues, ${ }^{71}$ provided that the time of mailing and the text of all literature be passed upon by the court after hearing all intervenors, so that, if opposite views be expressed by parties before the court,

68. Through their statements filed under $\$ 2 \mathrm{rr}$, and if required, through their proxy statements.

69. See supra p. 73.

70. Even a check of the Commission's records to investigate the acceptance or rejection of its views as expressed in the advisory reports would not tell the whole story without a detailed knowledge of the history of negotiation and compromise in each particular case.

7I. A good example would be to offer securityholders a choice between a program of reorganization or liquidation, or between two available types of capitalization. 
securityholders will receive full and fair statements substantially simultaneously.

\section{Conclusion}

Summarization of the developments under the reorganization acts and assessment of their desirability from the policy standpoint is not easy, nor can any expression be other than a personal view. Many aspects-some important-are untouched here. If others have been labored, let the desire for emphasis and clarity be pleaded in extenuation.

The federal equity receivership was not only a fictitious device used to accomplish a purpose for which it was not originally designed, but its very complexity made it malleable in the hands of expert technicians, sometimes to the substantial disadvantage of the small securityholder. Interests in charge of reorganizations were and are often selfseeking. They sometimes abused the broad discretionary powers given them by deposit agreements and paid themselves unconscionable compensation, free from court control. On the other hand, the reorganization bar chafed at the technicalities and fictions of equity procedure. The decision of the Boyd case ${ }^{72}$ and other decisions following it demonstrated the need for a method by which a final decree of undoubted validity, secure against direct or collateral attack, might be available for the accomplishment of a legitimate purpose-reorganization of a corporate enterprise-upon the basis of a plan approved by the court prior, not subsequent, to transfer of the properties. The necessity for financing payments to dissenting creditors was a serious obstacle and the upset price in many cases provided inadequate protection to the minority.

The reorganization acts have not removed the factor of complexity. Skill at reorganization practice is acquired only by experience and precedent still lies largely in the equity cases. The reorganization acts and particularly Chapter $X$, have charted the main steps in a proceeding, but the text alone cannot supply the technique for its expeditious use. Some of the statutory steps may in one case be factors making for delay, in another, necessary protections for the vital interests of minorities. Whereas the problem of obtaining jurisdiction over the debtor's property has been simplified, the problem of the personnel of management during the proceedings remains. Representation of scurityholders has been subjected to the requirement of full disclosure and the courts have acquired complete control of compensation to securityholder representatives. The problem of education of

72. Northern Pacific R. R. v. Boyd, 228 U. S. 482 (IgI3). 
the average securityholder to the need of intelligent representation throughout the proceeding and to an understanding of the material upon which his intelligent vote upon a plan should be based cannot be coped with by statute. The Securities and Exchange Commission has made and seems to be making a valiant effort at simplification of solicitation material, but there is some doubt as to the wisdom of the policy implicit in the statutory scheme of presenting to the rank and file of securityholders only a completed and approved plan. After the major portion of the proceedings has been completed, the burden placed upon the dissenter at this point is not so serious as that confronting the minority under equity practice. The opportunity to appear in the proceedings and express a dissenting voice at an earlier stage clearly exists under the statute. "Democratization" of reorganization practice-one of the objects of the Chandler Act-requires that that opportunity be widely exercised, but in the long run, the human problem remains and the effectiveness of the expression of the securityholder's. views in the course of the proceeding will be dependent upon the skill and experience of his counsel and, perhaps, the aid of the Securities and Exchange Commission staff.

Some experienced practitioners are reluctant today to appear in reorganization proceedings unless they represent substantial securityholdings, whether scattered or concentrated. It may be desirable that the representative of a single bond, sufficiently experienced and skilled to assume a major share of the burden of the proceeding or the negotiation of a plan, should be as well compensated as counsel for large holdings. The Bar at large and the courts do not, however, seem to have accepted this view. Either it must be accepted, or the road of a committee should be made easier. In the long run, only experience under the acts, and intelligent cooperation by participants in proceedings with the Commission and the courts can lead to constructive solution of problems such as this, and to further much needed improvement in reorganization practice and procedure. 